Tropical Journal of Pharmaceutical Research May 2016; 15 (5): 1013-1015

ISSN: 1596-5996 (print); 1596-9827 (electronic)

(C) Pharmacotherapy Group, Faculty of Pharmacy, University of Benin, Benin City, 300001 Nigeria.

All rights reserved.

Available online at http://www.tjpr.org

Original Research Article

http://dx.doi.org/10.4314/tjpr.v15i5.16

\title{
X-ray fluorescence spectroscopic determination of heavy metals and trace elements in aerial parts of Origanum sipyleum L from Turkey
}

\author{
Cenk Durmuşkahya ${ }^{1}$, Hakan Alp ${ }^{2}$, Zehra Sinem Hortooğlư ${ }^{3}$, Ümit Toktas ${ }^{4}$ and \\ Hüsniye Kayalar ${ }^{4 \star}$ \\ ${ }^{1}$ Department of Forest Engineering, Faculty of Forestry, Izmir Katip Celebi University, Balatcik, Izmir, ${ }^{2}$ Department of Chemistry, \\ Karadeniz Technical University, Trabzon, ${ }^{3}$ Center for Materials Research, Izmir Institute of Technology, Urla, ${ }^{4}$ Department of \\ Pharmacognosy, Faculty of Pharmacy, Ege University, Bornova, Izmir, Turkey
}

*For correspondence: Email: husniyekayalar@gmail.com; Tel: +905543986021

\begin{abstract}
Purpose: To determine the heavy metal and trace element composition of the powdered aerial parts of Origanum sipyleum $L$. and its water extract.

Methods: The heavy metal and trace elements content of the powdered plant material and $2 \%$ aqueous extract were evaluated by $x$-ray fluorescence spectroscopy with silicon drift detector SDD at a resolution of $145 \mathrm{eV}$ and 10,000 pulses. The process conditions were $0.1 \mathrm{~g}$ sample weight, process time of $300 \mathrm{~s}$ at a voltage of $25 \mathrm{kV}$ and $50 \mathrm{kV}$, and at a current of 0.5 and $1.0 \mathrm{~mA}$ under helium atmosphere. Results: The major elements, K, Ca and Na, known as macronutrients, constituted 11990, 10490 and $970 \mathrm{ppm}$ of the powdered drug and 8910, 2991 and $810 \mathrm{ppm}$ of the water extract, respectively. Among other constituents, arsenic, lead and uranium levels were < 1, 2.1 and $<3$ ppm, respectively, in the powdered material while in the aqueous extract, the levels were $<1,<2$ and 200 ppm, respectively. Conclusion: O. sipyleum is a potential source of macro- and micronutrients from which useful food additives and health supplements can be derived.
\end{abstract}

Keywords: Lamiaceae, Origanum sipyleum, Trace elements, Heavy metals, $X$-ray fluorescence

\begin{abstract}
Tropical Journal of Pharmaceutical Research is indexed by Science Citation Index (SciSearch), Scopus, International Pharmaceutical Abstract, Chemical Abstracts, Embase, Index Copernicus, EBSCO, African Index Medicus, JournalSeek, Journal Citation Reports/Science Edition, Directory of Open Access Journals (DOAJ), African Journal Online, Bioline International, Open-J-Gate and Pharmacy Abstracts
\end{abstract}

\section{INTRODUCTION}

Origanum species have been used as spices as well as for protection and treatment of various diseases in traditional medicine for thousands of years [1]. Aerial parts of Origanum species are used as diuretic, antitussive, antineuralgic and for improving stomach function and bronchial secretion. Origanum species, native to Cyprus, are also traditionally used against common cold and fever, and for spasmolytic actions and antirheumatic purposes via external application [2].
Origanum sipyleum, native to western Anatolia, where it is widely used as a spice and against gastrointestinal disorders and cough. This perennial plant, commonly known as "bayırçayırı", have been used as a medicinal tea, food additive and for the production of essential oil $[3,4]$.

Plants assimilate elements dissolved in water through their roots. In addition to purity, safety and efficacy assessments, a part of quality control studies on medicinal plant is the detection 
and quantification of heavy metals. Medicinal plants are taken in different forms such as teas, capsules, syrups and tablets containing ground or powdered form of pharmaceutical materials. Extracts prepared with different solvents are also used as active ingredients.

In the present work, the aim is to obtain a better understanding of the medicinal and nutritive composition of $O$. sipyleum, including heavy metals and trace elements, of the powdered plant material and water extract, using x-ray fluorescence spectroscopy.

\section{EXPERIMENTAL}

The aerial parts of Origanum sipyleum were collected from Spil Mountain, Manisa, Turkey. Dr Cenk Durmuşkahya from İzmir Katip Çelebi University authenticated the plant material and a voucher specimen (no. 1445) was deposited in the herbarium of Pharmacognosy Department, Faculty of Pharmacy, Ege University.

The aerial parts were collected, air-dried and ground into fine powder. Both the powdered plant material and the water extract prepared as a $2 \%$ infusion, were analysed for heavy metals and trace element using SPectro IQ II instrument equipped with dispersive $\mathrm{x}$-ray fluorescence (XRF) technology at a resolution of $145 \mathrm{eV}$ at 10,000 pulses for the SDD detector. Bragg crystal polarized the primary beam and highly ordered pyrolytic graphite (HOPG) was the target; other conditions include a duration of 300 $\mathrm{s}$ at a voltage of $25 \mathrm{kV}$ and $50 \mathrm{kV}, 1 \mathrm{~mA}$ helium atmosphere and 0.5 and $1.0 \mathrm{~mA}$ current.

\section{RESULTS}

It was observed that $O$. sipyleum aerial parts and its water extract contain significant values of elements. The results are shown in Table 1. Major elements such as $\mathrm{K}, \mathrm{Ca}$ and $\mathrm{Na}$, known as macronutrients, are detected at levels of 11990 , 10490 and $970 \mathrm{ppm}$ in the powdered drug and 8910, 2991 and 810 (ppm) in the water extract, respectively. Except for trace elements such as $\mathrm{Zn}, \mathrm{Cu}, \mathrm{Br}, \mathrm{Mo}, \mathrm{Mn}$ and $\mathrm{Ag}$, heavy metal contents were higher in the water extract than in the powdered material. The concentrations of toxic elements such as $\mathrm{Pb}, \mathrm{Cd}$ and As were low in both the powdered material and its water extract. Aluminum also regarded as a toxic element was present at a high concentration in the powdered material but was much lower in the extract. On the other hand, the water extract contained higher levels of $\mathrm{Cu}$ and $\mathrm{Zn}$ than the powdered drug.

Table 1: Metal content of powdered (OS) and water extract (OSw) of Origanum sipyleum

\begin{tabular}{|c|c|c|c|c|}
\hline $\mathbf{Z}$ & Symbol & Element & $\begin{array}{c}\text { OS } \\
\text { (ppm) }\end{array}$ & $\begin{array}{l}\text { OSw } \\
\text { (ppm) }\end{array}$ \\
\hline 11 & $\mathrm{Na}$ & Sodium & 970 & 810 \\
\hline 12 & $\mathrm{Mg}$ & Magnesium & 1050 & 643 \\
\hline 13 & $\mathrm{Al}$ & Aluminum & 4381 & 222.7 \\
\hline 14 & Si & Silicon & 782.3 & 266.7 \\
\hline 15 & $P$ & Phosphorus & 1387 & 704.4 \\
\hline 16 & S & Sulfur & 1972 & 1428 \\
\hline 17 & $\mathrm{Cl}$ & Chlorine & 578.5 & 552.4 \\
\hline 19 & $\mathrm{~K}$ & Potassium & 11990 & 8910 \\
\hline 20 & $\mathrm{Ca}$ & Calcium & 10490 & 2991 \\
\hline 22 & $\mathrm{Ti}$ & Titanium & 21.6 & 7.5 \\
\hline 23 & V & Vanadium & 5.1 & 6.5 \\
\hline 24 & $\mathrm{Cr}$ & Chromium & $<5.1$ & $<5.1$ \\
\hline 25 & $\mathrm{Mn}$ & Manganese & 120.1 & 162.8 \\
\hline 26 & $\mathrm{Fe}$ & Iron & 74.3 & 44.2 \\
\hline 27 & Co & Cobalt & $<3$ & $<3$ \\
\hline 28 & $\mathrm{Ni}$ & Nickel & $<2$ & $<2.4$ \\
\hline 29 & $\mathrm{Cu}$ & Copper & 33.7 & 879 \\
\hline 30 & $\mathrm{Zn}$ & Zinc & 49.2 & 2832 \\
\hline 31 & $\mathrm{Ga}$ & Gallium & $<1$ & $<1$ \\
\hline 32 & $\mathrm{Ge}$ & Germanium & $<1$ & $<1$ \\
\hline 33 & As & Arsenic & $<1$ & $<1$ \\
\hline 34 & $\mathrm{Se}$ & Selenium & $<1$ & $<1$ \\
\hline 35 & $\mathrm{Br}$ & Bromine & 4.9 & 468 \\
\hline 37 & $\mathrm{Rb}$ & Rubidium & 45 & 145 \\
\hline 38 & $\mathrm{Sr}$ & Strontium & 11.7 & 803 \\
\hline 39 & $\mathrm{Y}$ & Yttrium & 2.3 & 316 \\
\hline 40 & $\mathrm{Zr}$ & Zirconium & $<510$ & $<510$ \\
\hline 42 & Mo & Molybdenum & 13.2 & 1368 \\
\hline 47 & $\mathrm{Ag}$ & Silver & 26.5 & 3350 \\
\hline 48 & $\mathrm{Cd}$ & Cadmium & $<5.2$ & $<460$ \\
\hline 49 & In & Indium & $<5.1$ & $<5.1$ \\
\hline 50 & Sn & Tin & $<6.1$ & $<6.1$ \\
\hline 51 & $\mathrm{Sb}$ & Antimony & $<6.1$ & $<6.1$ \\
\hline 52 & $\mathrm{Te}$ & Tellurium & $<7.1$ & $<7.1$ \\
\hline 53 & I & lodine & $<7.1$ & $<7.1$ \\
\hline 55 & Cs & Cesium & $<8.1$ & $<8.1$ \\
\hline 56 & $\mathrm{Ba}$ & Barium & $<8.1$ & $<600$ \\
\hline 57 & $\mathrm{La}$ & Lanthanum & $<10$ & $<10$ \\
\hline 58 & $\mathrm{Ce}$ & Cerium & $<12$ & $<12$ \\
\hline 80 & $\mathrm{Hg}$ & Mercury & $<2$ & $<2$ \\
\hline 81 & $\mathrm{TI}$ & Thallium & $<2.9$ & $<2$ \\
\hline 82 & $\mathrm{~Pb}$ & Lead & 2.1 & $<2$ \\
\hline 83 & $\mathrm{Bi}$ & Bismuth & $<2$ & $<2$ \\
\hline 90 & $\mathrm{Th}$ & Thorium & $<2$ & 259 \\
\hline 92 & U & Uranium & $<3$ & 200 \\
\hline
\end{tabular}

\section{DISCUSSION}

$\mathrm{K}$ and $\mathrm{Na}$ is crucial for life and also play important roles during excitation and transmission in nerve cells. Ca, which promotes the quality of bones and teeth, also functions in the coagulation process $[5,6]$. The powdered plant material contained high levels of K (11990 ppm), Na (970 ppm) and Ca (10490 ppm), but were found in lower concentrations in the water extract. Trace elements such as $\mathrm{Fe}, \mathrm{Cu}, \mathrm{Ni}, \mathrm{Co}$, 
$\mathrm{Zn}, \mathrm{Mg}, \mathrm{Mn}$ and I, even in minute quantities in medicinal plants can have both curative and toxic effects. $\mathrm{Mn}, \mathrm{Cu}, \mathrm{Cr}$, and $\mathrm{Zn}$ are essential for the effective action of insulin.

Low levels of $\mathrm{Zn}$ have been detected in people suffering from diabetes and osteoporosis. The deficiency of this micronutrient is associated with impairment in growth leading to dwarfism [7]. Cu, which acts as a cofactor for a number of oxydase enzymes, plays a major role in Fe metabolism. $\mathrm{Cu}$ deficiency results in fragile bones and rupture of major vessels. Fe is an essential element in oxygen and electron transport [8]. $\mathrm{Zn}$ and $\mathrm{Cu}$ contents were high in the aqueous extract (2832 and $879 \mathrm{ppm}$ ), respectively, but Fe level was 74.3 and $44.2 \mathrm{ppm}$ for powdered drug and water extract, respectively.

\section{CONCLUSION}

To the best of our knowledge, this is the first report of the levels of some mineral and trace elements of $O$. sipyleum and its water extract. It should be useful to also study the levels of these elements of other traditionally used species from the same genus, as it may provide some insight into the therapeutic actions of the plant in various diseases. The findings show that $O$. sipyleum is a potential source of macro- and micro-nutrients and may be therefore find application as an additive in food and health supplements.

\section{ACKNOWLEDGEMENT}

The authors greatly acknowledge the valuable contributions of IYTE-MAM (IZTECH-CMR) members for their assistance in XRF measurement.

\section{CONFLICT OF INTEREST}

No conflict of interest associated with this work.

\section{CONTRIBUTION OF AUTHORS}

We declare that this work was done by the authors named in this article and all liabilities pertaining to claims relating to the content of this article will be borne by the authors.

\section{REFERENCES}

1. Fleisher A, Fleisher Z. Identification of Biblical Hyssop and origin of the traditional use of Oregano-group herbs in the Mediterranean region. Econ Bot 1988; 42(2): 232241.

2. Arnold N, Bellomaria B, Valentini G, Arnold HJ. Comparative study of the essential oils from three species of Origanum growing wild in the eastern Mediterranean region. J. Essent. Oil Res 1993; 5(1): 71-77.

3. Başer KHC, Tümen $G$, Özek $T$, Kürkçüoğlu $M$, Composition of the essential oil of Origanum sipyleum of Turkish origin, J Essent Oil Res 1992; 4, 139-142;

4. Köksal O, Güneş E, Özer OO, Özden M, Analysis of effective factors on information sources at Turkish Oregano farms, Afr J Agr Res 2010; 5(2): 142-149.

5. Seiler HG, Sigel A, Sigel H, Eds. Handbook on Metals in Clinical and Analytical Chemistry. Marckel Dekker, New York: 1984; $p 531$.

6. Khan $K Y$, Khan MA, Niamat R, Munir M, Fazal H, Mazari $P$, Seema N, Bashir T, Kanwal A, Ahmed SN. Element content analysis of plants of genus Ficus using atomic absorption spectrometer. Afr J Pharm Pharmacol 2011; 5(3): 317-321.

7. Salgueiro $M$, Zubillaga $M$, Lysionek $A$, Sarabia $M$, Caro $R$, De Paoli T, Hager A, Weill R, Boccio J. Zinc as an essential micronutrient: $A$. review. Nutr Res 2000; 20(5); 737-755.

8. Obiajunwa Eli Adeleke CA, Olanrewaju RO. Essential and trace element contents of some Nigerian medicinal plants. Trad Nucl Chem 2002; 252(3); 473-476. 